Caupolicán Montaldo

\title{
Lo anecdótico
}

\section{SERVICIOS DE TURISMO}

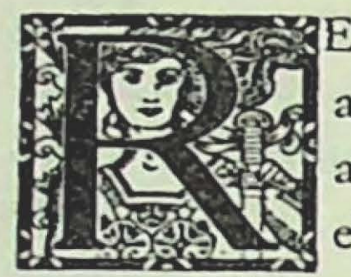

ESIDIAMOS por ese tiempo en Osorno, la bella ciudad austral, y nuestro esfuerzo periodístico tenía, entre otros afanes, el hacer notar lo agradable que resultaba para en otro tiempo, la sede de las nobles actividades de Vicente Pérez Rosales.

Supimos un día, con real alegría de nuestra parte, que don Enrique Molina y su señora habían llegado a Osorno, en viaje de descanso, tras el período en que él fuera el Ministro de Educación.

Don Enrique nos recibió con la cordialidad de siempre. En el hall del Hotel Burnier charlamos un momento mientras bajaba la señora Ester, la incomparable compañera del Maestro.

Para pasear un poco y aprovechar el tiempo, nos dirigimos los tres a la oficina que atendía entonces la representación de las Termas de Puyehue. Don Enrique pasaba por Osorno en dirección a las Termas.

Cuando llegamos a la oficina nombrada nos atendió un mozalbete, quien nos dijo que el empleado principal no estaba momentáneamente allí, pero él nos podría atender si queríamos algo.

Entonces don Enrique explicó: 
- Soy Enrique Molina, Rector de la Universidad de Concepción, y deseo llegar a las Termas de Puyehue, donde deben tener reservado un departamento a mi nombre. Yo les escribí hace algunos días. Entonces el muchachote, en tono que revelaba una suficiencia (?) total, preguntó:

- ¿Usted les escribió p’allá o escribió p'acá?

Pretendía aclarar si la carta había ido a Puyehue o a su oficina en Osorno.

Ya la forma de preguntar no era un dechado de cortesía. Pero don Enrique, pasando por alto el tonillo en que la pregunta fue hecha, aclaró, a su vez, suavemente:

-Escribí directamente a las Termas.

La respuesta fue:

-iAh! Güeno... ¡voy a llamar por teléfono, entonces!

$\mathrm{Y}$ tres minutos más tarde, comunicado ya con las Termas:

- Aló! Aquí hay un señor... (¿cómo se llama usté? Oiga, ¿cómo se llama usté?)

-Enrique Molina.

-... un señor que dice que se llama Enrique Molina, y dice, también (oiga, usté, ¿qué es lo que hace en Concepción?).

- Rector de la Universidad de Concepción.

-Y dice, también, que es Rector de Concepción. Y dice que escribió p'allá pidiendo una reserva de piezas.

En seguida, a don Enrique:

-Oiga, usté, van a ver si es cierto. Esperemos un ratito.

Esperamos. Usted, amigo lector, ¿no ha sentido nunca deseos criminales? Recuerde, como recordábamos nosotros, en ese instante, que nuestros mejores esfuerzos habían sido siempre el demostrar que Osorno, capital de la región de los lagos, era amable, discreta, atenta en todos sus aspectos, para el turista, atrayéndolo, previamente, por el buen servicio que todos sus habitantes ponían a disposición de quien llegara o pasara.

Y aquel pájaro oficinista, como ejemplo...

Sonó el teléfono. 
El señor representante y jefe accidental de la oficina, atendió. Cortó e informó:

-'Tá bien; 'tá reservá su pieza.

Don Enrique indicó entonces:

- Hágame el favor de decirle al chofer del auto de las Termas que nos pase a buscar.

-No hay auto. Hay micros.

Intervinimos:

- ¿A qué horas salen las micros?

- Una a la una de la tarde y la otra a las cinco.

- ¿Podría usted hacer reservar dos asientos en la micro de las cinco?

Y entonces el bípedo del otro lado del mesón, encogiéndose de hombros, respondió:

- A Ah, no! No hay reservas de asiento: el que llega primero llega no más. Y si no, se embroma...

Don Enrique nos miró. Se dio cuenta que algo nos iba a pasar. Nos tomó de un brazo y salimos, mientras decía:

-El pobre niño no sabe su oficio. Hay que perdonarlo.

Nadie en el mundo habría dicho eso.

Nos dolía todavía la cabeza cuando encontramos al agente del Banco de Chile en Osorno, que iba a buscar a don Enrique en su automóvil, para atenderle debidamente. Era quien corría con el negocio y ponía atención de verdad en el asunto turismo. No así, por cierto, el ejecutivo servidor que allí estaba de turno ese día. 